\title{
Žánr biografie v ruské tradici i v zahraniční literatuře
}

\author{
Marta Vágnerová (České Budějovice)
}

Biografija v istorii kul'tury. Sbornik statej. Ed. J. V. Ivanova. Moskva: Rutenija, 2018. 504 s.

ISBN 978-5-6041057-2-6.

Rozsáhlá kolektivní monografie s názvem Biografija v istorii kul'tury, která byla vydána Ústavem světové literatury A. M. Gorkého Ruské akademie věd v Moskvě s finanční podporou Ruského fondu základních výzkumů, se zabývá problémy vzniku a vývoje biografického žánru, přičemž mapuje jeho historicky proměnlivé funkce v současné ruské i zahraniční literatuře. Jde o tematicky širokou literárněvědnou problematiku vztahu autora a díla, která od absolutizace totální jednoty v pozitivisticko-psychologickém nazírání přecházela $\mathrm{k}$ psychoanalytické a hermeneutické relativizaci vzájemného propojení, jež tuto tematiku posouvalo třeba až ke studiu zkoumání pohlaví či rodu autora (gender studies). Autory článků jsou převážně vědci $\mathrm{z}$ různých ústavů Ruské akademie věd, at již přední dlouholetí pracovníci této instituce, nebo jejich mladší kolegyně a kolegové, ale i zástupci dalších pracovišt - Ruské státní humanitní univerzity, Tverské státní univerzity, Ústředního státního archivu Moskvy, Všeruského vědeckovýzkumného ústavu archivnictví a správy dokumentů. Kniha se skládá ze tř́i oddílů, které uvozuje vstupní studie Biografija v istorii kul'tury: tradicii, rol'v literaturnom processe, istočniki J. V. Ivanovové zachycující podrobný přehled teoretických přístupů ke studiu biografického žánru. Autorka rozebírá zejména práce W. Diltheye, G. Simmela, S. S. Averinceva a J. M. Lotmana. Poukazuje i na starší a dávné zdroje biografického žánru v evropské kultuře, která ovlivnila formování biografické tradice v ruské literatuře spolu s hagiografickými spisy staré ruské literatury. Právě v této hagiografické tradici Ivanova spatřuje původ toho, že při utváření biografického žánru v Rusku vystoupi- ly do popředí ideje služby vlasti a lidstvu, ideje přinesení oběti.

První oddíl, nazvaný Žanr biografii v zarubežnoj literature, obsahuje studie I. Šajtanova, J. P. Zykovové, O. A. Ovčarenka, Ž. M. Ivanovové de Mendosa a V. Vejdleho. Zatímco I. Šajtanov ve své stati Uil'jam Šekspir: obstojatel'stva i problemy tvorčeskoj biografii. Fakty, legendy, sluchi předkládá Shakespearův životopis nikoli jako souvislý a důvěryhodný narativ, ale jako posloupnost otázek vyvstávajících v souvislosti s tím, co je nám o něm známo z různých zdrojů, J. P. Zykovová v textu Sèmjuèl' Džonson: principy sozdanija literaturnoj biografii analyzuje principy tvorby literární biografie $\mathrm{v}$ dílech prvního velkého životopisce v anglické literatuře - S. Johnsona. Autorka dokládá, že Johnson pečlivě shromažd’oval dokumentární svědectví o soukromém životě svého hrdiny, k literární biografii přistupoval jako moralista a její cíl spatřoval $\mathrm{v}$ tom, aby čtenář byl přinucen zamyslet se nad „uměním života“. O. A. Ovčarenko v článku Biografija $\mathrm{Ka}$ moènsa: mify $i$ real'nost' konstatuje, že životopis velkého portugalského básníka je plný mýtů, protože nejsou známa dokonce ani data jeho narození a úmrtí. Autor článku zkoumá vznik a vývoj biografického mýtu kolem Camõense, počínaje prvním básníkovým životopiscem a konče autory biografií z let 1972-1980. Ž. M. Ivanova de Mendosa se ve svém článku Osobennosti žanra biografii v Latinskoj Amerike pokouší poprvé interpretovat proces vzniku a vývoje biografického žánru v latinskoamerické literatuře a prozkoumat jeho specifika. Při svém výzkumu došla $\mathrm{k}$ závěru, že biografický žánr byl v Latinské Americe prakticky vždy spjat s problémem národního sebeuvědomění, během svého vývoje 
ale prošel podstatnými změnami. Do prvního oddílu knihy je zařazen také text ruského historika umění, literárního a uměleckého kritika, esejisty a básníka V. V. Vejdleho, který od roku 1924 žil v Paříži. Tento text s názvem $O b$ iskusstve biografa z roku 1931, který dodnes nic neztratil na své aktuálnosti, představuje filozofické zamyšlení nad kvalitou životopisů vydávaných v Evropě v té době a nad tím, co je potřeba k sepsání dobré životopisné knihy. Článek opatřil úvodním slovem a poznámkami francouzský filolog a literární vědec, slavista René Guerra.

Druhý blok s názvem Biografičeskij žanr v russkoj tradicii je věnován problémům formování biografického žánru v ruské literatuře od nejstarších dob do současnosti. Podnětný článek L. I. Sazonovové Biografija pisatelja XVII v. v istoriko-kul'turnom kontekste: slučaj Simeona Polockogo je pokusem o doložení životní a tvůrčí pouti Simeona Polockého jako literární osobnosti. Sazonova rekonstruuje historicko-kulturní kontext vzniku biografie tohoto spisovatele a řeckokatolického kněze a upozorňuje přitom na řadu teoreticko-metodologických požadavků, které jsou kladeny na autora literární biografie spisovatele 17. století. S. G. Bočarov ve své stati Čto takoje biografija poèta zkoumá širší otázku - vzájemné vztahy mezi básníkovou biografií a jeho tvorbou a odraz těchto vztahů v biografii jako žánru. V článku V. I. Ščerbakova Stat'ja D. I. Pisareva: „Naša universitetskaja nauka" kak biografičeskij istočnik je Pisarevưv článek pojímán jako autobiografický dokument a memoárové svědectví o petrohradské univerzitě na přelomu padesátých a šedesátých let 19. století. Do oblasti dětské literatury směřuje článek A. J. Soročana Projekt Furmana: konstruirovanije biografii dlja detskogo čtenija, v němž autor dokládá, že spisovatel P. R. Furman vypracoval model biografického vyprávění, který byl aktuální ve 20. století. T. A. Kasatkina si ve své stati s názvem Čto sčitat' sobytijem biografii? Istorija ljubvi k Madonne: Puškin, Dostojevskij, Blok pokládá otázku, zda básníkovy prožitky lze považovat za biografickou skutečnost a pokouší se teoreticky definovat nutný rozsah událostí z umělcova života nezbytných $\mathrm{k}$ tomu, aby na- psaná biografie měla právo být považována za biografii daného umělce.

Třetí oddíl, nazvaný Biografija i jeje istočniki, má vztah k dokumentárním materiálům, na jejichž základě vznikaly životopisy básníků V. Majakovského a I. Severjanina, ale nalezneme zde rovněž články věnované vyšetřovacím spisům děkabristů a také našich současníků, kteří se stali obětmi stalinského teroru, jako biografickým zdrojům. Je sem zařazen i článek podávající přehled vědeckých prací v žánru kroniky života a tvorby spisovatelů a vědců a jejich využití k vytvoření vědeckých biografií. V. N. Ďadičev v článku Avtobiografičeskij očerk Majakovskogo «Ja sam»: mif i real'nost'. Opyt kommentarija komentuje autobiografickou črtu V. V. Majakovského napsanou v roce 1922. Zkoumá okolnosti a motivaci $\mathrm{k}$ napsání této črty, v komentáŕích k textu se opírá o nejvíce autoritativní svědectví básníkových současníků, o korespondenci, stati v periodikách té doby, o archivní dokumenty a další materiály. Cílem článku M. V. Skorochodova Letopis’ žizni i tvorčestva - naučnaja biografija: opyt sopostavitel'nogo analiza je vysledování vývoje biografických výzkumů v Rusku od počátku 20. století do současnosti. Autor provádí srovnávací analýzu kroniky života a tvorby a vědecké biografie včetně pramenů, struktury, zásad výběru materiálu. Článek autorek V. N. Těrechinovové a N. I. Šubnikovové-Gusevové $O b$ istočnikach biografii Igorja Severjanina je věnován analýze základních archivních dokumentárních pramenů biografie jednoho ze symbolů Stř́ibrného věku ruské poezie - Igora Severjanina. Na konkrétních př́kladech autorky rozebírají problémy vzájemného vztahu biografického mýtu a popisu života, jejich funkce v tvorbě, při formování biografického žánru. N. A. Sokolova a J. J. Lebeděva ve svém článku Sledstvennyje dela dekabristov: ješče raz o specifike istočnika analyzují vyšetřovací spisy děkabristů. Předmětem zkoumání je jeden z ústředních syžetů vyšetřování děkabristů - syžet tzv. „la garde perdue“, který se stal jedním ze stěžejních témat vyšetřovacího procesu a tedy i jedním ze základních bodů obžaloby. Z. P. Inozemceva ve stati Agiografija novomučenikov $i$ ispovednikov Cerkvi Russkoj. 
Problemy $i$ rešenija zkoumá historii a současnost hagiografie novomučedníků, otázky světonázorových rozdílů v pohledu na žánr životů svatých 20. století. Opírá se o materiály Synodní komise pro kanonizaci svatých, o práce současných hagiografů, historiků, odborníků na pomezní humanitní vědy a srovnává metodologické přístupy při zkoumání osobnosti používané v biografii a v hagiografii. Celou knihu uzavírá článek J. V. Ivanovové Sledstvennyje dela kak biografičeskij istočnik věnovaný problematice pramenoznalství - otázkám důvěryhodnosti informací zaznamenaných ve vyšetřovacích spisech epochy velkého teroru a možnostem jejich využití jako historického pramene. Jak autorka ukazuje na příkladu dvou odsouzených za domnělou účast na kontrarevolučním pravičácko-trockistickém spiknutí, tyto spisy neodpovídají skutečnosti, protože při jejich výrobě vyšetřovatelé používali metody fabrikace protokolů. J. V. Ivanova svým článkem polemizuje se statí Z. P. Inozemcevové, v níž je vyšetřovacím spisům této epochy přiznáván status historického svědectví.

Biografie literátů a kulturních činitelů byla tradičně považována za pomocný žánr, pohlíželo se na ni jako na pozitivistický doplněk a komentář $\mathrm{k}$ jejich dílu. Hlavním problémem byla proto její faktografická hodnota, důvěryhodnost, ale také vzájemný vztah mezi biografií a dílem, z něhož se zpětně vyvozoval autorův životopisný profil. V sovětské literatuře je biografický žánr spjat především se sérií Život významných lidi (Žizn' zamečatel'nych ljudej), vycházel z presumpce „významnosti“ a předmětem biografie se tak stala oslava lidských kvalit konkrétního subjektu. V literatuře 20. století se zformovala nová tendence - biografie se stala součástí tvorby, což je charakteristické zejména pro modernistické umělecké směry. Vznikl pojem „biografický mýtus“ a objevily se tendence k nahrazení reálné biografie jejím mytologizovaným invariantem. Na počátku 21. století se jako protiváha začala prosazovat postmoderní tendence k vytváření „demaskujících“ biografií bořících biografický mýtus, tendence k „demytologizaci“ biografií, které měly politicky oslavný, v podstatě ideologicky afirmativní rozměr. Můžeme tu doplnit, že tato tendence $\mathrm{k}$ desakralizaci biografického mýtu se objevovala již ve druhé polovině 20. století zejména u těch osobností, kde neexistoval dostatek empiricky ověřitelného životopisného materiálu. Takovou typickou osobností se stal např. slavný Shakespeare, jehož lidské osudy od poloviny 19. století vzbuzovaly řady rozporuplných interpretací. Monografie celkově ukazuje na potřebu teoretického studia biografického žánru a jeho vývoje v širokém literárněhistorickém kontextu světové kultury, na nutnost konceptualizace a odborné filologické analýzy. Jako předmět zkoumání se nabízejí různé aspekty tohoto tématu: biografie spisovatele jako součást díla, žánr biografie a žánr životopisu světců, biografie a hledání kladného hrdiny, biografický mýtus a jeho funkce ve vztahu k dílu, demytologizace a kritika biografických pramenů, dokument a biografický mýtus, funkce biografie v různých kulturně historických epochách a mnohé další. Monografie tvoří kompaktní celek, který rozšiřuje znalosti o vzniku a vývoji biografického žánru a přináší řadu nových poznatků a podnětných zamyšlení.

PhDr. Marta Vágnerová, Ph.D.

Katedra slovanských jazyků a literatur

Pedagogická fakulta, Jihočeská univerzita

Jeronýmova 10, 37115 České Budějovice, CZ

mvagner@jcu.cz

Toto dílo Ize užít v souladu s licenčními podmínkami Creative Commons BY-SA 4.0 International (https://creativecommons.org/licenses/by-sa/4.0/legalcode). Uvedené se nevztahuje na díla či prvky (např. obrazovou či fotografickou dokumentaci), které jsou v díle užity na základě smluvní licence nebo výjimky či omezení příslušných práv. 